\title{
SUGARS AND GLYCOLYTIC ENZYMES OF SPINAL FLUID IN EPIDEMIC CEREBROSPINAL MENINGITIS
}

\author{
By ROGER S. HUBBARD, NELSON G. RUSSELL, JR., AND NELLIE M. RUSSELL \\ (From the Buffalo General Hospital, Buffalo, New York)
}

(Received for publication May 20, 1936)

In a preliminary note (1) the presence in spinal fluid of a fermentable substance giving the resorcinol (fructose) reaction was reported. The present paper contains the results of analyses made upon specimens from two patients with meningitis due to the meningococcus. The results upon these cases are given in detail for three reasons. First, repeated punctures were made, and it was therefore possible to confirm results by repeated studies; second, some of the specimens were so large that certain experiments could be carried out which can usually be done only upon mixtures of fluid from several patients; third, the nature of the fluid made possible a study, not only of the sugars themselves, but also of the effect of glycolytic enzymes upon them.

\section{METHODS}

The methods used were the same as those previously employed. Protein was precipitated by zinc sulphate and sodium hydroxide in the proportions recommended by Somogyi (2). In working with spinal fluids the relatively low protein content made it possible to prepare filtrates containing a high proportion of the initial material; the proportions most commonly used were $1: 1.2$ and $1: 1.4$. Protein and the precipitated zinc were removed by centrifuging. Total reducing substances were determined in the supernatant fluid by the method of Folin and $W u(3,4)$, modified, when the sugar content was very low, as recommended by Hubbard and Allison (5). Fructose was determined by the method of Roe (6). Because very little fructose was found in some specimens, a series of standards was prepared from solutions of the pure sugar ranging in concentration from 0.1 to $4.0 \mathrm{mgm}$. per $100 \mathrm{cc}$. These were analyzed simultaneously with the blood or spinal fluid filtrate, and the " unknown" compared with the standard nearest to it in tint. This comparison was made in a colorimeter when the apparent concentration was greater than 1.0 mgm. per $100 \mathrm{cc}$; otherwise, the amount present was usually estimated by matching against a series of dilute standards in tubes of equal diameter. The accuracy of such determinations upon spinal fluid was approximately 0.1 to $0.2 \mathrm{mgm}$. per $100 \mathrm{cc}$. The accuracy upon blood and other fluids, which were diluted before analysis, was lower, and probably lay between 0.5 and $1.0 \mathrm{mgm}$. per 100 cc. Because glucose gave a slight color with the resorcinol reagent which closely resembled that given by fructose (1), correction tables based upon the analysis of pure glucose from the Bureau of Standards and of mixtures of this glucose with pure fructose were prepared. Since the "fructose" and other non-glucose reducing compounds contributed only a small fraction of the total reducing power of these fluids, the results of the Folin and Wu determinations were used as a basis for applying the appropriate corrections. These ranged from 0.0 to $0.4 \mathrm{mgm}$. per $100 \mathrm{cc}$. for the specimens of spinal fluid. The corrections of determinations upon blood plasma and serum were larger and amounted to as much as $2.0 \mathrm{mgm}$. per $100 \mathrm{cc}$. in some instances.

Both of the cases of meningitis upon which this report is based were typical. The diagnosis rested in each instance upon the presence of meningococci in smears and cultures prepared from the spinal fluid when the patients were first seen. Thereafter, the organisms were usually not found in the smears, but could often be recovered by an appropriate culture method. ${ }^{1}$ Both patients were treated by repeated injections of antimeningococcus serum into the spinal canal. Both eventually responded to the treatment in a satisfactory manner, but improvement was less rapid in Case 1 than in the second patient studied and was interrupted by two exacerbations of his condition. Brief reports of these cases are given below.

Case 1 was a white man, 21 years old, who was admitted October 31,1935 , in a semi-comatose condition. His temperature was $104^{\circ} \mathrm{F}$. Marked rigidity of the neck and a positive Kernig's sign were present. Knee jerks were absent. He had had headache, nausea and vomiting for 24 hours preceding admission. The spinal fluid was cloudy and under a pressure of $250 \mathrm{~mm}$. of water. The protein concentration was 0.49 per cent. The cell count was 2000 per c.mm., with polymorphonuclear leukocytes predominating. Diplococci with morphological and cultural characteristics of meningococci were found in a smear and recovered by culturing the fluid. Twenty cubic centimeters of New York State anti-

1 The microscopic and cultural examinations were carried out in cooperation with the bacteriological laboratory of the hospital. 
meningococcus serum were given intraspinally at once. The treatment used consisted of repeated spinal panctures and daily injections of from 20 to $30 \mathrm{cc}$. of specific serum into the spinal canal. In all, 15 punctures were made and $270 \mathrm{cc}$. of the serum given. The cell count remained very high until the 9th of November, when the cells numbered 280 per c.mm. At that time a negative culture was first obtained, and the temperature fell to normal by lysis. On November 14th the temperature was again high, the spinal fluid contained 1900 leukocytes per c.mm., and the culture was again positive. No positive cultures were obtained after this date, but the temperature was frequently very high and the cell counts in different specimens of spinal fluid varied markedly, for 4400 leukocytes per c.mm. were found on November 16th, 825 on the 18 th, 88 on the 20th, and 300 on the 22nd. During this period, either the type or the staining characteristics of the leukocytes varied quite markedly, for a predominance of eosinophilic cells was reported in several of the specimens. On the 5th of December, after the clinical condition of the patient had become practically normal, a specimen of spinal fluid containing 30 cells per c.mm. was obtained. These cells were classified as lymphocytes.

Case 2. The second patient was a girl 16 years old. She was admitted on December 17, 1935, giving a history of a cold which had lasted for 10 days. She had developed chilliness, a severe headache, and stiffness of the neck four days before she entered the hospital, and nausea, vomiting and a purpuric eruption on December 16th. She became delirious on the day of admission. She showed irritability, a stiff neck, a positive Kernig's sign, and a bilateral Babinski's sign. Her temperature was $105^{\circ} \mathrm{F}$. Spinal fluid obtained on admission contained 6600 cells per c.mm. and 0.31 per cent protein. Organisms resembling meningococci were found in the smear and on culture. Twenty cubic centimeters of therapeutic serum were injected into the spinal canal at once. Eleven spinal punctures were done during the succeeding nine days, and an injection of $20 \mathrm{cc}$. of the serum was given at the time of each puncture. Positive cultures of meningococci were obtained daily, and the cell count remained high until the 21 st, when a spinal fluid containing 170 cells per c.mm. was sterile on culture. Thereafter, the patient's condition improved rapidly, and a sterile specimen of fluid containing only 11 cells was drawn on December 28th. The cells were at all times considered to be polymorphonuclear leukocytes.

Besides determinations of the sugars in the different fluids made as soon as possible after they were obtained, the effect of incubation upon their apparent glucose and fructose content was studied. For this purpose fluids drawn with precautions to avoid bacteriological contamination were placed in an incubator at $37.5^{\circ} \mathrm{C}$. and the analyses repeated after various periods. In some instances control specimens were placed on ice and analyzed simultaneously with the incubated ones to reduce technical errors. The results of these determinations are given in Table $I$.
TABLE I

Sugars in spinal fluid before and after incubation $\ddagger$

\begin{tabular}{|c|c|c|c|c|c|c|c|}
\hline \multirow{2}{*}{ Case } & \multirow{2}{*}{ Material } & \multirow{2}{*}{ Date } & \multirow{2}{*}{$\begin{array}{l}\text { Incu- } \\
\text { bated }\end{array}$} & \multicolumn{2}{|c|}{$\begin{array}{c}\text { Before } \\
\text { incubation }\end{array}$} & \multicolumn{2}{|c|}{$\begin{array}{c}\text { After } \\
\text { incubation }\end{array}$} \\
\hline & & & & $\begin{array}{l}\text { "Glu- } \\
\text { cose" }\end{array}$ & $\begin{array}{l}\text { "Fruc- } \\
\text { tose" }\end{array}$ & $\begin{array}{l}\text { "Glu- } \\
\text { cose" }\end{array}$ & $\begin{array}{l}\text { "Fruc- } \\
\text { tose" }\end{array}$ \\
\hline \multirow{5}{*}{1} & & 1995 & hours & $\begin{array}{c}\text { mgm. } \\
\text { per } \\
100 c c .\end{array}$ & $\begin{array}{c}\text { mgm. } \\
\text { per } \\
100 \text { cc. }\end{array}$ & $\begin{array}{c}\text { mgm. } \\
\text { per } \\
100 c c .\end{array}$ & $\begin{array}{c}\text { mgm. } \\
\text { per } \\
100 \mathrm{cc} .\end{array}$ \\
\hline & Spinal fluid & $\begin{array}{l}\text { Nov. } 4 \\
\text { Nov. } 9 \\
\text { Nov. } 11 \\
\text { Nov. } 14 \\
\text { Nov. } 15 \\
\text { Nov. } 16 \\
\text { Nov. } 18\end{array}$ & $\begin{array}{l}24 \\
48 \\
24 \\
48 \\
72 \\
48\end{array}$ & $\begin{array}{l}6.7 \\
6.6 \\
55.0 \\
19.3 \\
42.8 \\
10.9 * \\
32.2\end{array}$ & \begin{tabular}{|l|}
1.2 \\
0.8 \\
3.5 \\
0.8 \\
0.9 \\
$0.6^{*}$ \\
0.8
\end{tabular} & $\begin{array}{r}2.0 \\
3.6 \\
53.0 \\
3.2 \\
2.8 \\
3.4\end{array}$ & $\begin{array}{l}1.2 \\
0.9 \\
3.0 \\
0.9 \\
0.8 \\
0.4\end{array}$ \\
\hline & & $\begin{array}{l}\text { Nov. } 19 \\
\text { Nov. } 20 \\
\text { Nov. } 21 \\
\text { Nov. } 30\end{array}$ & $\begin{array}{l}24 \\
24 \\
24\end{array}$ & $\begin{array}{l}31.5 \\
17.0 * \\
10.3 \\
53.0\end{array}$ & $\begin{array}{l}0.0 \\
0.2 \\
0.4^{*} \\
0.3 \\
0.8\end{array}$ & $\begin{array}{r}26.5 \\
18.4 \\
2.4\end{array}$ & $\begin{array}{l}0.3 \\
0.2 \\
0.3\end{array}$ \\
\hline & Blood & $\begin{array}{l}\text { Nov. } 4 \\
\text { Nov. } 14 \\
\text { Nov. } 16\end{array}$ & & $\begin{array}{r}96.6 \\
111.0 \\
103.0\end{array}$ & $\begin{array}{l}0.5 \\
0.0 \\
0.2\end{array}$ & & \\
\hline & Plasma & Nov. 16 & & 113.0 & 0.1 & & \\
\hline \multirow[t]{5}{*}{2} & Spinal fluid & $\begin{array}{l}\text { Dec. } 16 \\
\text { Dec. } 17 \\
\text { Dec. } 17 \\
\text { Dec. } 18\end{array}$ & 24 & $\begin{array}{l}1.2 \\
3.3 \\
9.1 \\
6.1\end{array}$ & $\begin{array}{l}0.2 \\
0.5 \\
0.7 \\
0.7\end{array}$ & 2.5 & 0.6 \\
\hline & & $\begin{array}{l}\text { Dec. } 19 \\
\text { Dec. } 19 \\
\text { Dec. } 20 \\
\text { Dec. } 21\end{array}$ & $\begin{array}{l}24 \\
24 \\
24\end{array}$ & $\begin{array}{l}16.3 * \\
12.5 * \\
27.0 \\
41.3\end{array}$ & $\begin{array}{l}1.2 * \\
0.7 * \\
0.7 \\
1.0\end{array}$ & $\begin{array}{l}2.7 \\
2.8 \\
4.2\end{array}$ & $\begin{array}{l}1.0 \\
0.7 \\
0.8\end{array}$ \\
\hline & & $\begin{array}{l}\text { Dec. } 23 \\
\text { Dec. } 28\end{array}$ & 24 & $\begin{array}{l}45.0 \\
55.7\end{array}$ & $\begin{array}{l}1.0 \\
1.5\end{array}$ & $\begin{array}{l}44.4 \\
43.4 \dagger\end{array}$ & $\begin{array}{l}1.0 \\
1.2 \dagger\end{array}$ \\
\hline & Blood & $\begin{array}{l}\text { Dec. } 17 \\
\text { Dec. } 20 \\
\text { Dec. } 28\end{array}$ & & $\begin{array}{l}135.0 \\
100.0 \\
103.0\end{array}$ & $\begin{array}{l}0.3 \\
0.0 \\
0.7\end{array}$ & & \\
\hline & $\begin{array}{l}\text { Therapeutic } \\
\text { serum }\end{array}$ & & & 20.0 & 0.0 & & \\
\hline
\end{tabular}

* The control specimen was kept on ice and analyzed simultaneously with the incubated one.

$t$ Many red blood cells were present in this specimen of spinal fluid.

t Under "glucose" is given the total reducing substances in terms of glucose, and under "fructose" a quantitative measure of the intensity of the resorcinol reaction as fructose. Results of determinations of fructose have been corrected for the slight resorcinol reaction given by pure solutions of glucose of the same concentrations as those present in the solutions analyzed.

The results show that both glucose and fructose were apparently present in most of the specimens, although the amounts were low in some instances. A low glucose content of fluid from patients with meningitis due to the meningococcus has been repeatedly observed; in this respect epidemic meningitis does not differ from other similar conditions. The fructose concentration of the fluid in these two cases was also low, for most of the results were between 90 and 50 per cent lower than those found in most normal fluids. Such a finding was not unexpected, for some parallelism between the amounts of glucose and fructose in normal spinal fluids was found by Hubbard and Garbutt (1) ; furthermore, those authors reported 
that no fructose was found in one specimen of a fluid from which glucose was absent. Hubbard and Garbutt suggested, as a possible explanation for the presence of fructose in spinal fluid, that the sugar might be formed from glucose in the spinal canal by a molecular rearrangement similar to that which glucose undergoes in alkaline solutions. The finding of low values for both sugars in the cases of meningitis reported here may perhaps be interpreted as evidence in favor of such an hypothesis, but there are so many other factors which might affect the finding, such as the abnormal physical and chemical nature of the spinal fluid, the presence of a pathological process in the spinal canal, the introduction of the serum used in the treatment, etc., that it seems dangerous to emphasize the support which these observations seem to lend to the theory previously suggested.

Table I shows that, after incubation, the concentrations of reducing substances were usually lower than were those found when the control specimens were analyzed. The eleven fluids which showed this difference were cloudy and had a high protein content, ${ }^{2}$ the three which did not were much more nearly normal in appearance and contained reducing substances in amounts approximating those found in normal fluids. Two of these specimens were taken from the first patient during remissions; the other was obtained from the second patient when recovery was almost complete.

Although incubation brought about a marked decrease in the reducing power of most of the specimens studied, it caused little or no alteration in their "fructose" content. The average decrease in concentration was $0.06 \mathrm{mgm}$. per $100 \mathrm{cc}$. In only 2 of the 14 specimens did the concentration fall by more than $0.2 \mathrm{mgm}$. per $100 \mathrm{cc}$. Both of these were fluids of approximately normal composition which did not show a significant drop in reducing power after incubation.

\footnotetext{
2 The results of cell counts made upon the various fluids ranged from 100 to 6600 per c.mm. These counts were made as soon as possible after the specimens were taken. Most of the fluids contained fibrin, and many of the cells became entangled in the web which formed quite promptly. Figures obtained in the counts made before the clot formed, therefore, bore little relationship to the concentration of cells suspended in the incubated fluid. The results have, therefore, been omitted in preparing the table.
}

The fall in the total reducing power observed must have been due largely to destruction of glucose. Results of the order of magnitude of those found can be explained in no other way. Since this destruction of glucose was not accompanied by a significant change in the intensity of the corrected " fructose" reaction, the positive resorcinol test must have been caused by some substance other than glucose.

Figures showing the apparent fructose content of the blood and plasma of the patients and of the serum used in the treatment are also shown in Table I. It is evident that the amount of this compound present was low in each instance. The significance of the figures is questionable for two reasons. The color measured in the dilute filtrates was very faint, and corresponded to that given by fructose solutions containing between 0.1 and $0.2 \mathrm{mgm}$. of the sugar in $100 \mathrm{cc}$. In each instance the color given by solutions of pure glucose similar in concentration to those contained in the dilute filtrates would account for between 75 and 100 per cent of all the color found. It is evident, therefore, that no quantitative significance can properly be attached to the figures, and it seems questionable whether the results definitely prove the presence of any fructose or fructoselike substance in the blood, serum, and plasma analyzed.

Various experiments were carried out to determine the mechanism by which incubation brought about a decrease in the reducing power of these spinal fluid specimens. When specimens were kept on ice for 24 hours no destruction of " glucose" or " fructose" could be demonstrated. When cells were removed by centrifuging and the supernatant fluid incubated, there was also no reduction in the concentration of either of the "sugars." The results of these experiments agree with the commonly accepted theory $(7,8)$, that much of the glycolytic enzyme in spinal fluid is contained in the cells and bacteria.

The results of the following experiment further confirm the impression that the glycolytic enzyme was contained in the cells, and show further that the sugars in fluid from meningococcic meningitis were probably not different from those found in normal fluid. Five cubic centimeters of a fluid rich in cellular elements, which was obtained from 
the second patient, were centrifuged under sterile precautions. The supernatant fluid was discarded and replaced by $5 \mathrm{cc}$. of a " normal" fluid obtained during a diagnostic encephalogram. The cells were then suspended in the normal fluid, and the tube and its contents incubated at $37.5^{\circ} \mathrm{C}$. for 24 hours. A similar suspension of cells in sterile 0.85 per cent sodium chloride was treated in a similar manner. The next day the cells were removed by centrifuging, and the total reducing power and "fructose" content of the supernatant fluids determined. Analyses of a specimen of the normal fluid which had been incubated without the addition of cells and of another which had been kept on ice 24 hours were made simultaneously. The reducing power of the normal fluid was almost completely destroyed in the presence of the cells (a drop in concentration of $45 \mathrm{mgm}$. of "glucose" per $100 \mathrm{cc}$. from an initial value of $50 \mathrm{mgm}$. was observed), but the "fructose" content fell only $0.4 \mathrm{mgm}$. from an initial value of $2.3 \mathrm{mgm}$. Neither "glucose" nor "fructose" was found in the salt solution in which the cells had been incubated, nor was there any significant difference between the amounts of the two sugars in the specimen incubated without the addition of cells, the fluid kept on ice, and the control specimen analyzed soon after the fluid was drawn.

It seemed desirable to determine whether pure fructose could be added to a spinal fluid rich in cells and be recovered after incubation. The sugar was dissolved in sterile 0.85 per cent sodium chloride solution and added to such a specimen of spinal fluid obtained from Case 1 to give an additional fructose concentration of $0.5 \mathrm{mgm}$. per $100 \mathrm{cc}$. An equivalent amount of the saline was added to a duplicate sample of the same spinal fluid. Both specimens were incubated at $37.5^{\circ} \mathrm{C}$. for 48 hours. Ninety-five per cent of the 40 mgm. of "glucose" contained in $100 \mathrm{cc}$. of these specimens was destroyed during this incubation. The added fructose was recovered quantitatively.

\section{DISCUSSION}

It has been shown that the enzymes in the cellular elements in these fluids caused certain changes in the sugars which were present. The enzymes may have been contained either in the organisms or the leukocytes. Smears were prepared from fresh samples of all of the specimens studied and organisms demonstrated in only two of them. Smears were also made from centrifuged material after incubation and organisms recovered in only one instance. Such findings are common in material from active cases of meningococcic meningitis $(9,10)$, and make it seem probable that the leukocytes contained the active agent. However, when suitable culture methods were used, meningococci could be demonstrated in many of the fluids, and Mader (11) has shown that glucose is sometimes destroyed when that organism is added to spinal fluid. Thirteen specimens of " normal" spinal fluid, including two obtained from Case 1 after recovery, were, therefore, heavily inoculated with meningococci and incubated for periods of 24 to 96 hours under conditions identical with those used in the experiments reported above. In 8 of these specimens there was no growth of organisms. In 5, a rather scanty growth occurred, and in only 2 of the whole series was there a measurable destruction of sugar. In neither of these experiments did the changes in concentration of sugar resemble those shown in Table I, for, in one instance, both glucose and fructose were apparently completely destroyed and in the other a destruction of 50 per cent of the glucose and of 90 per cent of the fructose was found. These experiments make it seem probable that the changes shown in Table I were not brought about by organisms in the spinal fluid studied, but by enzymes present in the leukocytes.

In the previous communication (1) it was reported that the substance giving the resorcinol (fructose) reaction was destroyed by short incubation with large amounts of yeast. This observation was confirmed upon material from each of these two cases. The method used was similar to those described by Hiller, Linder and Van Slyke (12), Somogyi (13), and Benedict (14). Large amounts $(0.25 \mathrm{cc}$. to $2.5 \mathrm{cc}$.) of centrifuged, washed yeast cells were introduced into 5 cc. portions of the fresh and the incubated spinal fluid. The mixtures of the fluid and yeast were then placed in the incubator at $37.5^{\circ} \mathrm{C}$. for 15 to 20 minutes. No " fructose" could be demonstrated in specimens which had been treated in this way, and the reducing power. was markedly lower than it had been before the yeast was added. 
The apparent glucose content was between 1 and 2 mgm. per $100 \mathrm{cc}^{3}$ Values of this order of magnitude have been repeatedly obtained in studies of spinal fluid made in this laboratory. They apparently represent some non-sugar reducing substance which is quite regularly present in spinal fluid.

To confirm these results with yeast and to exclude the rather remote possibility that the resorcinol reaction in spinal fluid was due to sucrose, a strain of bacterium coli, which did not attack that sugar but which did destroy glucose and fructose, was used. A specimen of spinal fluid from Case 1 was heavily inoculated with these organisms and incubated for 24 hours. After this period the results of a resorcinol test were completely negative. The apparent glucose content was $1.2 \mathrm{mgm}$. per $100 \mathrm{cc}$. These results with yeast and bacterium coli can be adequately explained if the specimens contained glucose, fructose (or some compound closely resembling fructose), and a small amount of non-fermentable reducing substance. It seems very difficult to interpret them in any other way.

\section{SUMMARY}

In specimens of spinal fluid from two patients with meningococcic meningitis a substance giving a typical positive test for fructose by Roe's (6) method was present. The biological properties of this substance were apparently identical with those of fructose. By incubating specimens of this fluid the concentration of the reducing substances was markedly diminished, while the concentration of the "fructose" was little altered.

\footnotetext{
3 In two instances the incubation with cells and the treatment with yeast were carried out upon duplicate specimens of spinal fluid. The average of the values after 15 minutes incubation with yeast was $1.5 \mathrm{mgm}$. "glucose" per $100 \mathrm{cc}$., while the corresponding value after 24 hours incubation with cells was $3.9 \mathrm{mgm}$. The accuracy of the determinations of such small concentrations of "sugar" is, of course, low, but the difference between the figures is probably significant. The difference seems too great to be wholly attributed to "fructose," which was destroyed by the yeast but was wholly unaffected by the cells, for an average concentration of only $0.9 \mathrm{mgm}$. of that sugar per $100 \mathrm{cc}$. of fluid was found in these specimens. The difference was probably due in part to "fructose" and in part to glucose, which apparently was not wholly destroyed by the incubation with the cells.
}

The glycolytic enzyme affecting the change seemed to be present in the leukocytes, for the change was not observed when specimens were freed from cells before incubation, nor was it found in spinal fluids which were inoculated with meningococci and incubated under comparable conditions.

The authors wish to express their thanks to Dr. Clayton W. Greene and Dr. Byron D. Bowen for permission to study the first case discussed, and to Dr. Walter H. Krombein for permission to study the second case.

\section{BIBLIOGRAPHY}

1. Hubbard, R. S., and Garbutt, H. R., Resorcinol (fructose) reaction in cerebrospinal fluid. Proc. Soc. Exper. Biol. and Med., 1935, 32, 986.

2. Somogyi, M., A method for the preparation of blood filtrates for the determination of sugar. J. Biol. Chem., 1930, 86, 655.

3. Folin, O., and Wu, H., A system of blood analysis. J. Biol. Chem., 1919, 38, 81.

4. Folin, O., and $W u, H$., A system of blood analysis. Supplement I. A simplified and improved method for determination of sugar. J. Biol. Chem., 1920, 41, 367.

5. Hubbard, R. S., and Allison, C. B., Residual reduction in blood filtrate after treatment with colon bacillus. Proc. Soc. Exper. Biol. Med., 1928, 25, 408.

6. Roe, J. H., A colorimetric method for the determination of fructose in blood and urine. J. Biol. Chem., 1934, 107, 15.

7. Peters, J. P., and Van Slyke, D. D., Quantitative Clinical Chemistry. Volume I. Interpretations. Williams and Wilkins Co., Baltimore, 1931, p. 191.

8. Katzenellenbogen, S., The Cerebrospinal Fluid and Its Relation to the Blood. Johns Hopkins Press, Baltimore, 1935, p. 156.

9. Wadsworth, A. B., Standard Methods of the Division of Laboratories and Research of the New York State Department of Health. Williams and Wilkins Co., Baltimore, 1927, p. 232.

10. Zinsser, H., and Bayne-Jones, S., A Text-Book of Bacteriology. D. Appleton-Century Co., New York, 1934, 7th ed., p. 427.

11. Mader, A., Uber Ursach und Bedeutung der Zuckerveränderungen im Blut und Liquor bei zerebralen Erkrankungen des Kindes. Jahrb. f. Kinderh., 1930, 126, 187.

12. Hiller, A., Linder, G. C., and Van Slyke, D. D., The reducing substances of the blood. J. Biol. Chem., 1925, 64, 625.

13. Somogyi, M., Reducing non-sugars and true sugar in human blood. J. Biol. Chem., 1927, 75, 33.

14. Benedict, S. R., The determination of blood sugar. II. J. Biol. Chem., 1928, 76, 457. 